\title{
Mapping and monitoring geomorphological processes in mountainous areas using PSI data: Central Pyrenees case study
}

\author{
G. Herrera $^{1}$, J. C. Davalillo ${ }^{1}$, J. Mulas ${ }^{1}$, G. Cooksley ${ }^{2}$, O. Monserrat ${ }^{3}$, and V. Pancioli ${ }^{4}$ \\ ${ }^{1}$ Área de Peligrosidad y Riesgos Geológicos, Departamento de Investigación y Prospectiva Geocientífica, \\ Instituto Geológico y Minero de España (IGME), c/ Alenza 1, 28003 Madrid, Spain \\ ${ }^{2}$ Altamira Information, c/ Còrsega, 381-387, 2n 3a, 08037 Barcelona, Spain \\ ${ }^{3}$ Instituto de Geomática, Av. Canal Olímpic s/n, 08860 Castelldefels, Spain \\ ${ }^{4}$ Department of Earth Sciences, University of Florence, via La Pira 4, 50121 Firenze, Italy
}

Received: 15 April 2009 - Revised: 24 July 2009 - Accepted: 25 August 2009 - Published: 24 September 2009

\begin{abstract}
In this paper the Stable Point Network technique, an established Persistent Scatterer InSAR (PSI) technique, (SPN), has been applied for the first time to the analysis of several geomorphological processes present in the Gállego river basin (Central Pyrenees, Spain). The SPN coherence based approach has been used to process three different SAR images datasets covering two temporal periods: 1995 to 2001 and 2001 to 2007. This approach has permitted the detection of more than 40000 natural ground targets or Persistent Scatterers (PSs) in the study area, characterised by the presence of vegetation and a low urban density. Derived displacement maps have permitted the detection and monitoring of deformations in landslides, alluvial fans and erosive areas. In the first section, the study area is introduced. Then the specifics of the SPN processing are presented. The deformation results estimated with the SPN technique for the different processed datasets are compared and analysed with previous available geo-information. Then several detailed studies are presented to illustrate the processes detected by the satellite based analysis. In addition, a comparison between the performance of ERS and ENVISAT satellites with terrestrial SAR has demonstrates that these are complementary techniques, which can be integrated in order to monitor deformation processes, like landslides, that over the same monitoring area may show very different ranges of movement. The most relevant conclusions of this work are finally discussed.
\end{abstract}

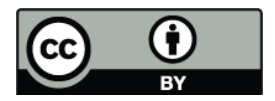

Correspondence to: G. Herrera (g.herrera@igme.es)

\section{Introduction}

Ground movements in mountainous areas are a very frequent phenomena due to rainfall intensity, the strong topographical gradients, and the presence of intensely weathered and tectonised material. In these environments, landslides, erosion or compaction of unconsolidated soils are common active processes that are responsible for ground deformation, and amongst which landslides produce the greatest socioeconomic impact on human activity. In this sense, the impact of landslides for the Spanish territory has been addressed by the statistical analysis of the data collected in recent years by the Ministry of the Environment and the Geological and Mining Institute of Spain (IGME). In these studies the total amount of damage caused by landslides in Spain has been estimated at 160 million/year for the period 1986-2016 (Ferrer, 1995), and a total of 56 deaths were attributed to ground movements between 1995-2007 (MMA, 2008). Therefore in order to prevent or reduce the impact of hazards associated to ground movements, a thorough understanding of their governing and triggering mechanisms, their spatial distribution and state of activity is necessary.

Thus, advanced remote sensing techniques based on satellite radar data have become a powerful method to detect and monitor slow ground surface deformations. Synthetic aperture radar images (SAR) acquired by ERS-1, ERS-2 and ENVISAT European Space Agency (ESA) satellites provide a wide coverage of $100 \mathrm{~km} \times 100 \mathrm{~km}$, a high spatial resolution of $20 \mathrm{~m} \times 4 \mathrm{~m}$ and the availability of a long historical archive of SAR images acquired since 1991. The conventional differential interferometry (DInSAR) methods compare two SAR images acquired in different moments over the same area, permitting the detection of ground surface deformations that have occurred between the acquisition dates of both images.

Published by Copernicus Publications on behalf of the European Geosciences Union. 

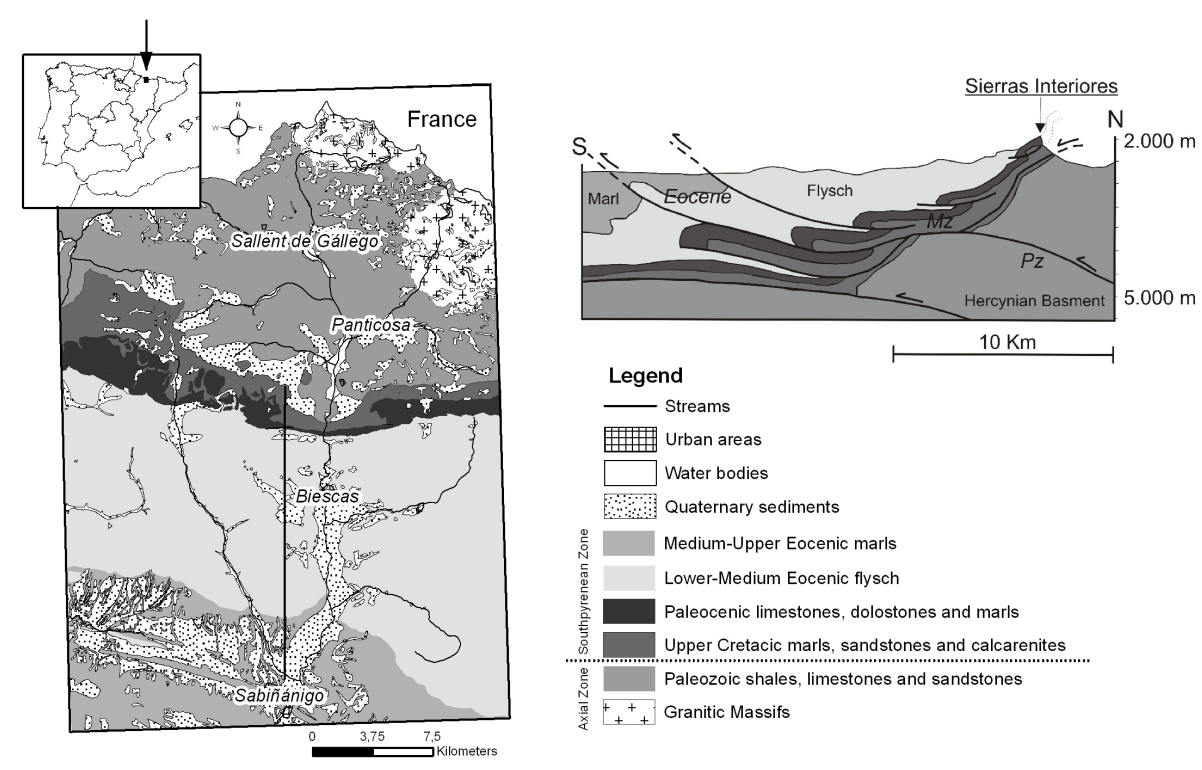

Fig. 1. Geological context of the Gállego River basin area.

Several authors have applied conventional DInSAR to landslide investigations (Carnec et al., 1996; Rott et al., 1999; Berardino et al., 2003; Catani et al., 2005; Strozzi et al., 2005; Corsini et al., 2006), but significant limitations related to temporal and geometric decorrelation can be noted.

These limitations have been partially resolved by the advanced DInSAR methods that make use of large sets of SAR images, acquired in different moments over the same area, permitting the detection of deformation areas and the observation of the temporal evolution of the displacement of every detected natural reflector with millimetric precision and high spatial resolution. The first Persistent Scatterer Interferometry (PSI) method, namely the Permanent Scatterers technique $\left(\right.$ PSInSAR $^{T M}$ ), was developed by Ferretti et al. (2001). It was then followed by other authors, who developed similar methods (Mora et al., 2003; Arnaud et al., 2003; Werner et al., 2003; Hooper et al., 2004; Pepe et al., 2005; Crosetto et al., 2005). To date, most of the PSI applications have focused on subsidence analysis and few landslide applications are available (Colesanti et al., 2003; Hilley et al., 2004; Farina et al., 2006; Meisina et al., 2006, Raetzo et al., 2007, Pancioli et al., 2008).

This paper presents the first application of the Stable Point Network (SPN) algorithm (Arnaud et al., 2003) to mapping and monitoring geomorphological processes in mountainous areas. In this case the SPN coherence based approach has been used to process three different SAR images datasets covering two temporal periods from 1995-2001 and from 2001-2007 over River Gallego basin (Central Spanish Pyrenees). PSI derived displacement maps have permitted the detection and monitoring of displacements in landslides, alluvial fans and erosive areas. In the first section, the study area is introduced. Then the details of the SPN processing are presented. The deformation results estimated with the SPN technique for the different processed datasets are compared and analysed with previously available geo-information from a regional perspective. In section five, several detailed studies are presented in order to illustrate the processes detected by the satellite based analysis. Finally, a comparison between the satellite and terrestrial SAR data is presented and the most relevant conclusions of this work are discussed.

\section{Study area and previous information}

The study was carried out in the Gállego River basin, located in the Central Pyrenees (Huesca, Spain). The basin extends over an area of $850 \mathrm{~km}^{2}$. The Gállego River descends from 2000 to $800 \mathrm{~m}$ a.s.l. in Sabiñánigo, located in the southern part of the study area. The North of the study area is formed by the magmatic and Palaeozoic complex of the axial Pyrenees. The Central and southern part is occupied by the folded Flysh and Eocene marls of the Inner Depression. The contact of these units is occupied by the Mesozoic and Tertiary calcareous rocks of the Inner Sierras. Overlying these materials are Quaternary deposits found in topographic depressions (Fig. 1). Many authors have studied the geomorphological aspects of landslides in the upper part of the Gallego River basin (García-Ruiz et al., 1995a,b; and García-Ruiz et al., 2004). Large deep seated landslides developed in highly altered and tectonised Palaeozoic slates on the Western part of upper the Gállego River. Rock falls and rock avalanches are also found in Palaeozoic limestones. The action of glaciers on the granitic massifs shaped steep slopes and reliefs favouring the occurrence of falls, topples and rock avalanches. Most of the debris flows occur on the 
highly alterable Eocene Flysh (Lorente et al., 2003), where moraine deposits and alluvial fans are characteristic (GómezVillar et al., 2000). Glacis and different terrace levels of the Inner Depression are affected by badlands (Nadal-Romero et al., 2007). The climate in this area is characterised by a marked seasonality, classified as of the Mediterranean mountain type with Atlantic and Continental influences (Creus and Gil, 2001). The average annual precipitation varies from $2000 \mathrm{~mm}$ in the North to $800 \mathrm{~mm}$ in the South, with rainfall concentrated mainly in spring and autumn, followed by winter and with punctual intense convective storms during the summer. Part of the study area is covered by forests. However forests have been replaced by cultivated fields that were abandoned in the middle of the 20th century (García-Ruiz and Lasanta, 1990).

A landslide inventory and susceptibility map at 1:25000 of the Gállego River basin was made in 1995 by the Geological and Mining Institute of Spain (Fig. 2). The landslide inventory map was produced using conventional methods: literature and ancillary data compilation, aerial-photo interpretation and field surveys (Soeters and van Westen, 1996).

Mapped mass movements include rockfalls and rock avalanches, rotational and translational landslides, flows and solifluctions, along with information about the state of activity. When the morphological characteristics and the representation scale allowed, the boundaries of the deposition area were mapped together with the detachment scarp. Some old movements, whose deposits have been eroded, are represented only by their main scarp. In other cases only the deposition area has been depicted. The susceptibility assessment method used by Mulas and Fresno (1995) was a "heuristic" analysis according to Aleotti and Chowdhury (1999) classification. Conditioning factors considered for the susceptibility analysis were the slope, the lithology, the structural context, the altitude, the vegetation and the erosive action of the basin drainage network. As a result of this analysis four level of susceptibility to landslides were defined ( $\mathrm{c}$ in Fig. 2). The lithological groups were classified according to the resistance and weathering susceptibility of the rock formations, and their geomorphological characteristics, identifying the expected type of mass movements in each of them (Table 1).

\section{SPN technique and SAR dataset processing}

\subsection{SPN technique}

The SPN is an advanced differential interferometric processing technique (Arnaud et al., 2003; Duro et al., 2005). It is the result of several years of research projects within the DInSAR data analysis field for CNES (French Space Agency), ESA and Altamira Information SL. The SPN chain was the first advanced interferometric processor capable of merging the new ASAR data with the historical ERS-1/2 data (Arnaud

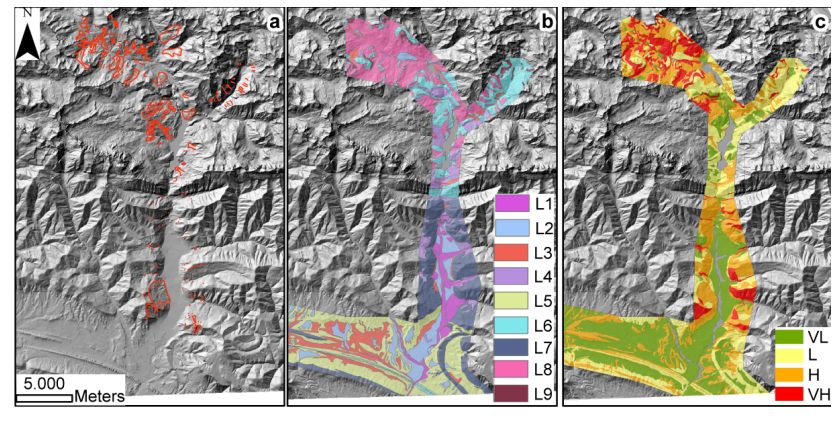

Fig. 2. (a) Landslide inventory features map; (b) Lithological map (see Table 1 for legend); (c) Landslide susceptibility map: VL: Very Low; L: Low; H: High; VH: Very High (based on Mulas and Fresno, 1995).

Table 1. Lithological classification (based on Mulas and Fresno, 1995).

\begin{tabular}{llll}
\hline & Formation & Type of expected movement & $\begin{array}{l}\text { Resistance and } \\
\text { weathering alterability }\end{array}$ \\
\hline L1 & $\begin{array}{l}\text { Alluvial fans and end of the } \\
\text { valley deposit }\end{array}$ & no movement & \\
L2 & Glacis and terrace deposit & landslide, fall or topple & \\
L3 & Colluvial deposit & landslide and flow & \\
L4 & Moraine deposit & landslide and flow & low and high \\
L5 & Marls & creep and flow & high and low \\
L6 & Granitic rocks and limestones & rock fall & variable and high \\
L7 & Flysh and sandstones & landslide and flow & high and high \\
L8 & Slates, shales, sandstones and & landslide & \\
& greywackes & rock flow & \\
L9 & Rock avalanche deposit & & \\
\hline
\end{tabular}

et al., 2003). SPN software uses the DIAPASON interferometric chain for all SAR data handling, e.g. co-registration work and interferogram generation.

Figure 3 gives an overview of the SPN processing chain: the SPN procedure generates three main products starting from a set of SLC SAR images: the displacement rate that can be derived using a dataset of at least 6 images; a map of height error; and finally, the displacement time series, which requires at least 20 images, depending on the velocity of displacement with respect to the temporal separation of image acquisitions. Nevertheless, an increase in the number of SAR images improves the quality of the measurements, providing an error of $1 \mathrm{~mm} /$ year for subsidence rates and 2 $\mathrm{m}$ for height errors. The basis of the SPN technique is the separation of different components from the interferometric phase, $\Phi_{\text {INTERF }}$, the topographic component, $\Phi_{\text {TOPO }}$, the movement component, $\Phi_{\mathrm{MOV}}$, the atmospheric contribution, $\Phi_{\mathrm{APS}}$, and the noise component, $\Phi_{\mathrm{NOISE}}$;

$\Phi_{\mathrm{INTERF}}=\Phi_{\mathrm{TOPO}}+\Phi_{\mathrm{MOV}}+\Phi_{\mathrm{APS}}+\Phi_{\mathrm{NOISE}}$

One important characteristic of this chain is its flexibility; the software can work at any resolution, any frequency and with sub-images. The SPN algorithm can either work at full 


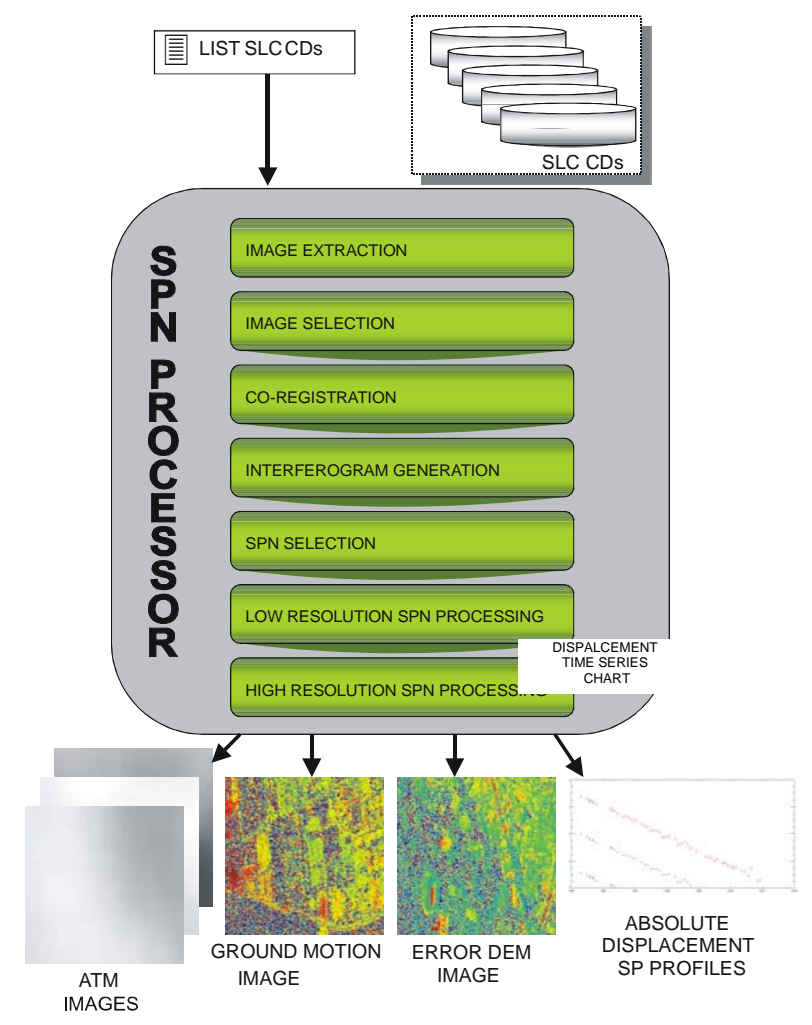

Fig. 3. Stable Point Network processing chain main flow chart.

resolution ( 4 by $20 \mathrm{~m}$ ) selecting the measurement points by analysing the amplitude of the set of SAR images, or at reduced resolution (for example 40 by $40 \mathrm{~m}$ ) selecting ground surface natural reflectors or Persistent Scatterers (PS) by interferometric coherence. The amplitude selection mode is based on analysing the temporal stability of the electromagnetic response to the radar signal (backscattering) for each pixel of the study area. If the geometry of the ground surface that corresponds to a certain pixel does not vary significantly along time, the backscatter is similar for every acquired SAR image, and the pixel is selected as a PS. The coherence based approach, performs an average of the backscattering of neighbour pixels increasing the measurement point density. In fact, this approach is particularly useful for non-urban and vegetated areas where ground surface scatterers (buildings, structures, metallic objects) are scarce. A detailed description of the SPN algorithm can be found in Crosetto et al. (2008) where some examples of urban subsidence monitoring are shown. To date the performance of the SPN method has been mainly validated in subsidence analysis (Herrera et al., 2009, Raucoules et al., 2009).

\section{SAR dataset processing and results}

A dataset of SAR images acquired by descending orbits of ERS-1, ERS-2 and ENVISAT satellites over River Gállego basin was obtained from the ESA archive. A total of $106 \mathrm{im}-$ ages were acquired covering the period from 1995 to 2007. The SPN method was used to process three SAR datasets containing descending SAR images available from two temporal periods from 1995 to 2001 and from 2001 to 2007 and ascending data from 2002-2007 In this case, the SPN coherence based processing was carried out at medium resolution ( 40 by $40 \mathrm{~m}$ ) with the aim of detecting active geomorphologic processes in non urban and vegetated areas at a regional scale, covering an area of $720 \mathrm{~km}^{2}$. The results of this processing are summarised in Table 2 and shown in Fig. 4. It is observed that the total amount of PSs extracted in the ascending 2002-2007 period is half that obtained for the descending 2001-2007 period, the ascending analysis being constrained by the data availability and thus the ability to identify PSs, a critical issue that affects the density and the quality of PSs estimates retrieved with PSI processing chains.

Considering the three processed datasets, a total of 45668 PSs have been detected in the Gállego River basin study area with an average spatial density of $21 \mathrm{PSs} / \mathrm{km}^{2}$, and a displacement rate range of +16 to $-39 \mathrm{~mm} /$ year. Note that SPN displacements are measured in the Line Of Sight (LOS), which is the line defined by the satellite incidence angle and the ground surface reflector. A positive value corresponds to a displacement towards the satellite along the LOS, whereas a negative value is a displacement in the opposite direction. From the total amount of PSs only $17.3 \%$ have a displacement velocity greater than $1.5 \mathrm{~mm} /$ year (hereafter displacement PSs). Analysing the PSs distribution among the slope classes, one can observe that $40.5 \%$ of them are concentrated in Valley Bottom areas (slope angle between $0-3^{\circ}$ ), whereas $59.5 \%$ of the PSs are found in hilly and mountainous areas $\left(3-90^{\circ}\right)$. The PSs density in hilly and mountainous areas drops to $13 \mathrm{PSs} / \mathrm{km}^{2}$.

\section{SPN analysis}

\subsection{Landslide inventory analysis}

The SPN landslide inventory analysis was performed following a similar methodology to that proposed by Farina et al. (2006). The PSs were overlaid upon the pre-existing landslide inventory in order to evaluate the main differences in terms of spatial distribution and state of activity of landslides with respect to SAR measurements. Two particular situations have required a significant effort on the interpretation of moving SP. The first one is those landslides only defined by scarps with no landslide boundaries or vice-versa; or landslides only represented by arrows indicating the direction of movement. The other situation occurs when active SPs are located far from any mapped landslide. In these cases, the support of photo-interpretation, aspect and hill shaded DEM derived products, topographic map and geomorphological map (García-Ruiz et al., 1995a,b) analysis 
Table 2. SPN analysis on the Gállego River basin.

\begin{tabular}{|c|c|c|c|c|}
\hline & $\mathrm{N}^{\circ}$. SAR images & $\mathrm{N}^{\circ}$. PSs & $\mathrm{PS} / \mathrm{km}^{2}$ & $\begin{array}{c}\mathrm{N}^{\circ} \text {.displacement } \\
\text { PSs }\end{array}$ \\
\hline Descending orbit 1995-2001 & 39 & 18579 & 26 & 3175 \\
\hline Ascending orbit 2002-2007 & 29 & 9089 & 13 & 1257 \\
\hline Descending orbit 2001-2007 & 38 & 18000 & 25 & 3458 \\
\hline Total & 106 & 45668 & & 7890 \\
\hline
\end{tabular}

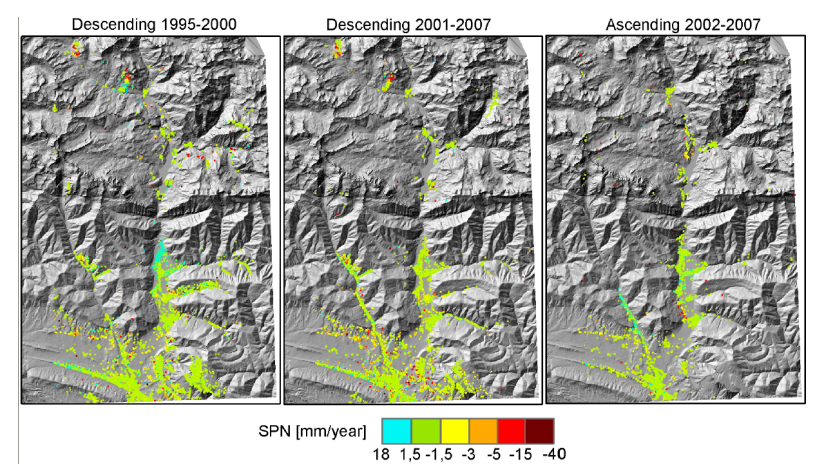

Fig. 4. SPN displacement velocity maps retrieved over the Gállego River basin.

was used to detect diagnostic morphologies. In fact the use of pre-existing information was fundamental to detect other superficial active processes in the Gállego River basin.

The SPN results permitted the detection of a total of $23 \%$ of the landslides inventoried by Mulas and Fresno (1995), 31 new small landslides within their study area, and 51 new landslides beyond the boundary of their study area. Therefore the updated landslide inventory consists of 145 landslides where $5.7 \%$ of the PSs are found. An average of 20 PSs are obtained per landslide, even though in 47 landslides only 1 PS has been found (Table 3). Figure 5 shows the detected slope instabilities, from which $22 \%$ correspond to landslides, $23 \%$ correspond to falls and topples and $55 \%$ have been classified as flows. Nevertheless, it must be taken into account that most of the detected PSs in landslides correspond to previously deposited rock accumulations affected by other landslide mechanisms. Only in some cases could the detected PSs be related to precursor displacements of rock falls or topples. In the following section, detected landslide mechanisms are illustrated in the Portalet and Formigal landslides.

The SPN analysis has also permitted the detection and monitoring of other active processes of the study area, such as alluvial fans and erosive areas. In fact, the greatest amount of PSs, $20,7 \%$ of the total, is found in alluvial fans with an average density of $788 \mathrm{PSs} /$ deposit $\left(2000 \mathrm{PSs} / \mathrm{km}^{2}\right)$. In these formations, most of the detected PSs are stable and only $13.4 \%$ of them show displacement. $8.4 \%$ of PSs are found in areas characterised by erosive processes
Table 3. Statistical analysis of the SPN detected active superficial processes.

\begin{tabular}{lcccccc}
\hline & $\mathrm{N}^{\circ}$. & $\mathrm{N}^{\circ} . \mathrm{PSs}$ & $\%$. PSs & $\begin{array}{c}\% \\
\text { displacement } \\
\text { PSs }\end{array}$ & $\begin{array}{c}\text { Average } \\
\text { area }\left[\mathrm{km}^{2}\right]\end{array}$ & $\begin{array}{c}\text { Average } \mathrm{N}^{\circ} . \\
\text { PSs }\end{array}$ \\
\hline Landslides & 32 & 633 & 1,4 & 64,0 & 0,46 & 20 \\
Falls and topples & 33 & 907 & 2,0 & 57,1 & 0,15 & 27 \\
Flows & 80 & 1060 & 2,3 & 41,1 & 0,09 & 13 \\
Erosion & 72 & 3845 & 8,4 & 31,0 & 0,07 & 57 \\
Alluvial fans & 14 & 9452 & 20,7 & 13,4 & 0,46 & 788 \\
\hline
\end{tabular}

(57 PSs/deposit) where $31 \%$ of the PSs show displacement. A more detailed analysis of the nature of the displacement in each of the detected process is presented in section five.

\subsection{SPN lithological map analysis}

The displacement velocity maps have been compared to the pre-existing lithological map (Mulas and Fresno, 1995). To enable this comparison, two analyses are proposed: (1) to analyse the lithological distribution of the PSs found within the inventoried geomorphological processes; (2) to restrict this analysis only to the inventoried landslides. For this purpose, the following values were calculated for each lithological group described in Table 1: the number of PSs; the number of displacement PSs; and the average velocity of the displacement PSs found within each lithological aerial extent. In Fig. 6a it is observed that $56 \%$ of the PSs are found in alluvial and end of the valley deposits, and marls (L1, L5). One can observe that more stable than displacement PSs are found in L1 formations, whereas the opposite is observed for marls. This is in agreement with Table 1 were it is shown that no slope instabilities are expected for alluvial deposits (L1). Eocene marls (L5) present a greater amount of displacement PSs due to the low resistance and high weathering susceptibility that favours the occurrence of flows and creep according to Table 1, which is probably associated with erosive processes. If we only consider the inventoried landslides (Fig. 6c) we observe that rock formations account for $88 \%$ of the PSs and higher displacement rates than the other formations. In this analysis slates and sandstones (L8) account for $31 \%$ of the PSs and $41 \%$ of the displacement PSs. Note that in the study area these materials are characterised by intense weathering an high plasticity and are usually covered by rock fall or avalanche deposits favouring the detection of natural reflectors or PSs. Therefore detected displacements are probably due to the transportation of rock deposits by other landslide mechanisms, e.g. the slow soil flows described by García-Ruiz et al. (2004) characteristic from the Upper Gállego River basin. In section five Portalet and Formigal landslides illustrate this type of landslide mechanisms. 


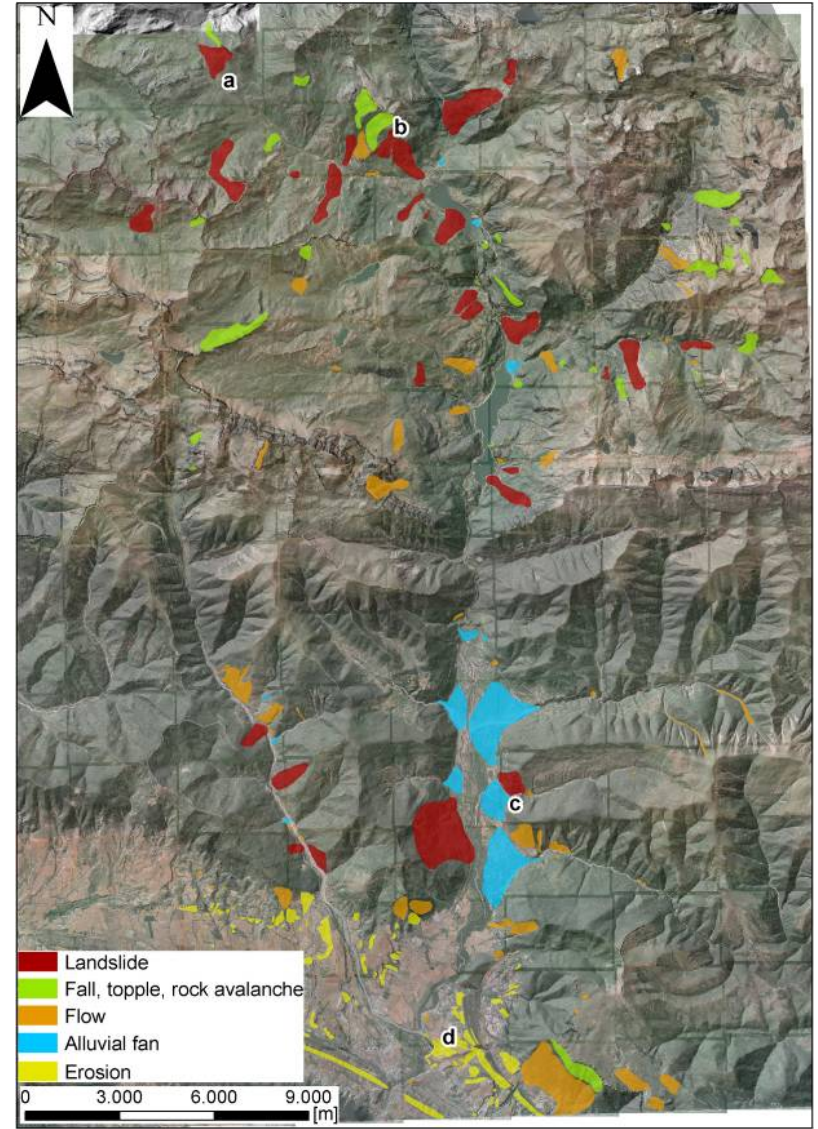

Fig. 5. SPN detected superficial active processes: (a) Portalet landslide, (b) Formigal landslide; (c) Oros alluvial fan; (d) Latas badlands.

\subsection{SPN susceptibility map analysis}

In this part, the estimated displacement velocity is compared with the landslide susceptibility map (Mulas and Fresno, 1995). This map classifies landslide susceptibility into four classes: Very Low (S1), Low (S2), High (S3) and Very High (S4), following a heuristic approach described in section 2. To enable this comparison, two analyses are proposed: (1) to analyse the PSs distribution within each susceptibility level found within the detected geomorphological processes; (2) to restrict this analysis only to the inventoried landslides. For this purpose, the following values were calculated: the $\%$ of PSs; the \% of displacement PSs, and the average velocity of each susceptibility level. In Fig. $6 \mathrm{~b}$ it is shown that the greatest amount of PSs is found in the "Very Low" and "Low" landslide susceptibility level decreasing gradually towards the "High" susceptibility level. This is because most of the PSs are found in alluvia, end of the valley deposits, glacis and terrace deposits (L1, L2) where landslide susceptibility is "Very Low" and "Low". In fact, as it will be discussed later on, displacements in these formations are probably re-
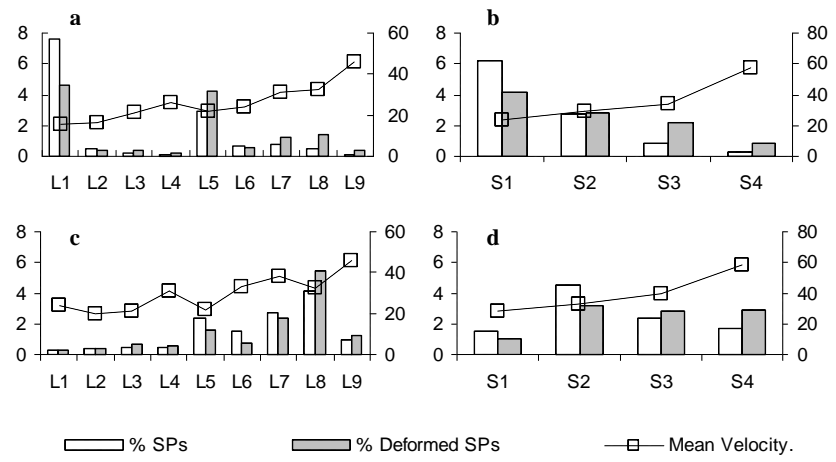

Fig. 6. (\% in the $Y$ right axis) and average velocity ( $\mathrm{mm} / \mathrm{year}$ in the $Y$ left axis) of each lithological unit: (a) analysis 1; (c) analysis 2; and each landslide susceptibility area: (b) analysis 1; (d) analysis 2 .

lated to compaction processes rather than slope instabilities. On the other hand if this analysis is restricted to landslides we observe that $73 \%$ of the stable PSs are found in "Low" and "Very Low" levels, whereas $57 \%$ of measured displacements are concentrated on "High" and "Very High" landslide susceptibility classes. Finally, one can observe that the greater the average absolute velocity, the greater the landslide susceptibility level. Therefore there appears to be a good correlation between SPN displacement measurements and the pre-existing landslide susceptibility assessment.

\section{SPN local analysis}

\subsection{Landslide analysis}

The Portalet landslide is located in the North-Western area of the upper part of the Gállego River basin, near the border with France. On this site, two pre-existing landslides (García-Ruiz et al., 2004) develop from 1850 and $1600 \mathrm{~m}$ a.s.l. along a Southwest facing hillside, slightly altering the route of the Gállego River to the South (Fig. 7). Both landslides affect the weathered bedrock composed mainly of Carboniferous and Devonian slates and shales characterised by an intense weathering and a high plasticity. Rock fall and rock avalanche deposits found at the upper part of the slope (1 and 2 in Fig. 7) are transported downhill by the slow flow of landslide B deposit. The slope excavation at the foot of the slope, carried out in order to build a car park in the summer of 2004, reactivated both landslides, generating new sliding surfaces (C in Figs. 7 and 8 ) that affected the road to France. A geotechnical survey detected the failure surfaces of landslide $\mathrm{C}$ and $\mathrm{A}$, and also identified the materials involved (Torrijo Echarri, 2005). Measurement of the displacements performed with D-GPS and GB-InSAR revealed that the moving mass was still active after the constructive solutions were undertaken (Herrera et al., 2008). 


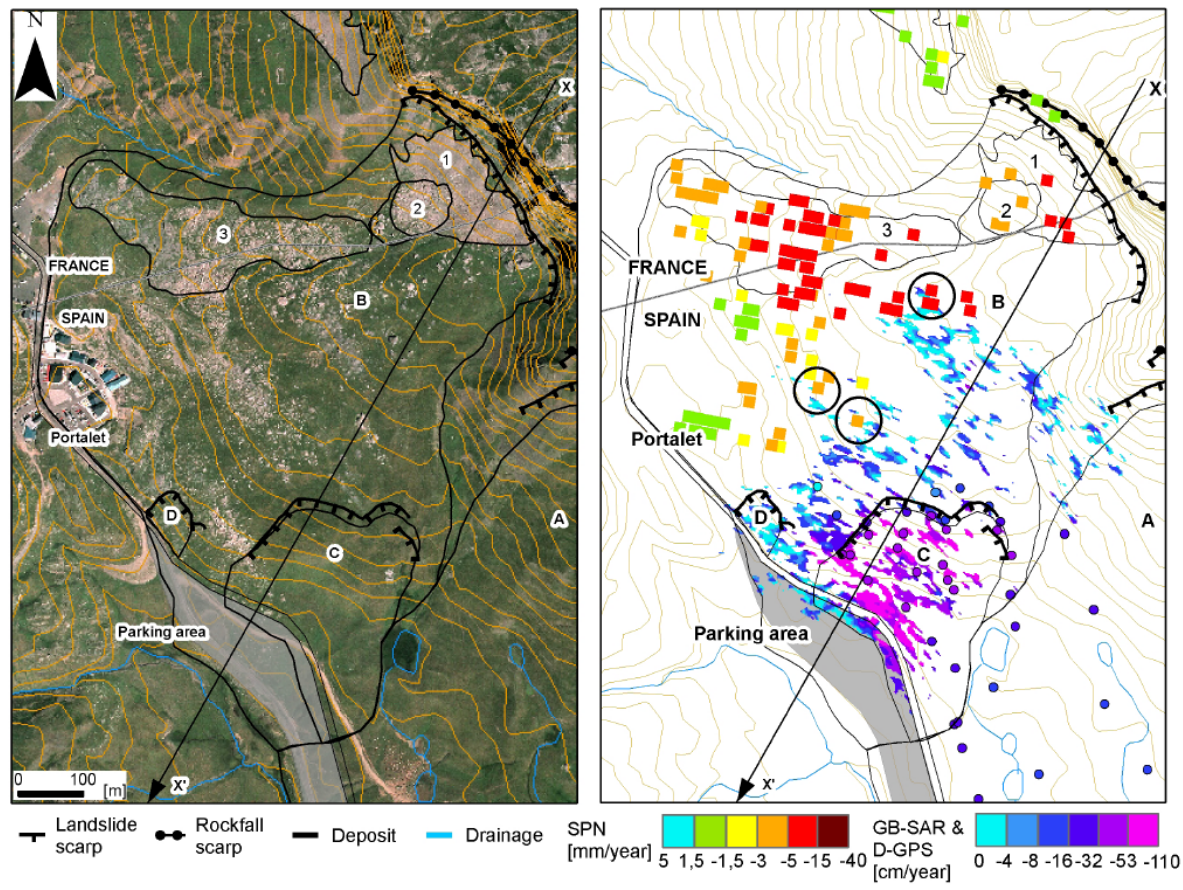

Fig. 7. Map of the Portalet landslide showing the displacement velocity estimated with: the SPN technique between 1995-2007; the GBInSAR (pixels) in the period September-December 2006; and D-GPS (circles) in the period May 2006-July 2007.

In this case, the SPN analysis has provided an assessment of the state of activity before the excavation of the parking area in 2004, during the period of 1995-2000 when no other instrumental data was available. PSs displacements are measured in the satellite Line Of Sight (LOS), which is the line defined by the satellite incidence angle and the ground surface natural reflector (Fig. 8). A positive value corresponds to a displacement towards the satellite along the LOS, whereas a negative value is a displacement in the opposite direction. During this period, 36 PSs were detected on rock avalanche and rock fall deposits (1,2 and 3 in Fig. 7) detached from the limestone cliff located on top of the hill. These deposits are transported by a slow flow (landslide B in Figs. 7 and 8) downhill towards the Portalet urban area. In the first period, detected displacement rates vary from +0.1 to $-7.1 \mathrm{~mm} / \mathrm{year}$, and are very similar to the values of the 87 PSs detected during the period of 2001-2007. Therefore, since measured displacement velocities have been constant for both periods analysed, it can be deduced that the excavation of the parking area in 2004 did not affect this part B of landslide, but only part C of it (Fig. 7). No PSs were detected in landslide $\mathrm{C}$ due to the absence of rock deposits, the presence of low vegetation and the (high) magnitude of the displacement velocity. As for the satellite, the ground based radar (GB-InSAR) displacements are measured in the Line Of Sight (LOS), which is the line defined by the ground based radar incidence angle and the ground surface natu- ral reflector. In this case a negative value corresponds to a displacement towards the radar along the LOS, whereas a positive value is a displacement in the opposite direction. The ground based radar (GB-InSAR) measured displacement rates of up to $-1095 \mathrm{~mm} /$ year in 11254 natural reflectors between September and November 2006 (Fig. 7), while the D-GPS measured up to $-529 \mathrm{~mm} /$ year of displacement between May 2006 and July 2007 in 45 ground control points (circles in Fig. 7). A total of $41 \mathrm{~GB}-\mathrm{InSAR}$ natural reflectors $(2 \mathrm{~m} \times 2 \mathrm{~m})$ coincide with 3 PSs $(40 \mathrm{~m} \times 40 \mathrm{~m})$ detected in the descending orbit 2001-2007 period (black circles in Fig. 7). If we compare measured displacements projected along the slope direction in the coinciding period, between September and November 2006, the SPN technique measured a displacement between -3 and $-6 \mathrm{~mm}$, whereas GBInSAR measurements vary between -2 and $-16 \mathrm{~mm}$, which are similar values but within the error of both advanced remote sensing techniques.

The Formigal landslide is situated in the North-Western sector of the upper part of the Gállego River basin. Several landslides develop between 2200 and $1500 \mathrm{~m}$ a.s.1. (A, B, C and D in Fig. 9), and have been previously described by García-Ruiz et al. (2004). This movement involves slates and Foratata limestones from the middle Devonian age, characterised by an intense weathering and a high plasticity. Talus debris fan, rock falls and avalanche deposits are found at the base of the limestone cliffs accumulated on topographic 


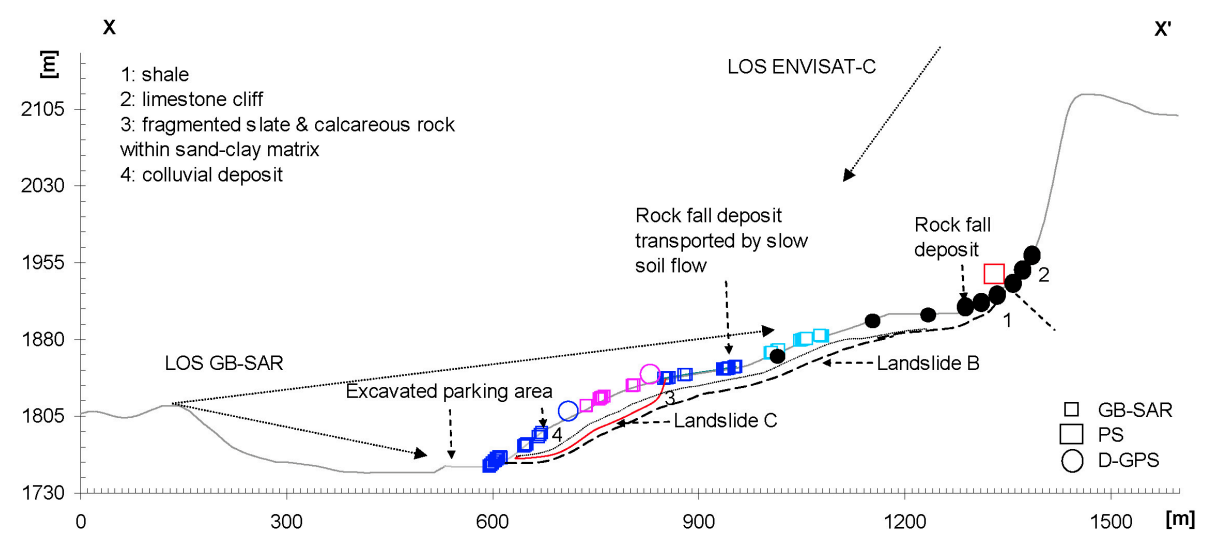

Fig. 8. Simple geological profile of the Portalet area (XX' in Fig. 7). The deformation values follow the colour scale of Fig. 7.

depressions (1 and 2 in Fig.9). These deposits are affected by slow soil flow that transports rock blocks downhill towards Formigal (3 in Fig. 9). In this case, a total amount of $443 \mathrm{PSs}$ were detected from the top to the toe of landslide $\mathrm{B}$, with displacements rating from +3.6 to $-16.1 \mathrm{~mm} / \mathrm{year}$. All these detected PSs correspond to rock blocks that are transported by the slow soil flow (landslide B in Fig. 9). One can observe that the velocities decrease downhill according to the decrease of the slope angle. Hence, velocities below $-15 \mathrm{~mm} / \mathrm{year}$ are found on top, between 1830 and $1700 \mathrm{~m}$ a.s.l. soil flow rates vary from -5 to $-15 \mathrm{~mm} / \mathrm{year}$, and between -5 and $-1.5 \mathrm{~mm} /$ year in the middle part where rock blocks are smaller and sparsely distributed. Finally, at the bottom part of the soil flow, the displacement rate varies between -1.5 and $+3.6 \mathrm{~mm} /$ year, showing an uplift of the toe of the landslide, which is probably associated to the deceleration of the moving mass and the presence of an accumulation zone (in this area the average slope angle is $5^{\circ}$ ). In the case of landslide $\mathrm{A}$, with similar characteristics to those of Landslide B, only a few PSs have been detected, even though there is a significant amount of rock deposits. This is due to the slope's North-South orientation, which is roughly perpendicular to the ERS/Envisat look direction and to which the satellite has minimal sensitivity. In the case of landslides $\mathrm{C}, \mathrm{D}$ and $\mathrm{E}$, the absence of significant rock deposits and urban areas, as well as the slope orientation, prevented the detection of PSs.

\subsection{Alluvial fans analysis}

Alluvial fans are common landforms that develop at valley junctions due to the sudden fluvial energy reduction caused by a change in the topographic gradients (Bull, 1979). Large alluvial fans within the study area have their catchments in the Eocene Flysh sector where landslides, flows, rills and active ravines constitute the main source of sediment sources (Gómez-Villar and García-Ruiz, 2000). In the Gállego River basin, a total amount of 9452 PSs have been found in 14 al- luvial fans, (an average of $788 \mathrm{PSs} /$ deposit). Most of the detected PSs within the alluvial fans are stable since only $13,4 \%$ of them correspond to displacement PSs, whose displacement rates vary between -6 and $+12 \mathrm{~mm} /$ year. The nature of the few positive displacement PSs randomly distributed in the alluvial fans may not be attributed to any expected geomorphological processes in the area.

In Fig. 10a, the Oros alluvial fan is shown. This deposit extends over an area of $0.69 \mathrm{~km}^{2}$, where four different sectors can be distinguished according to fluvial activity and vegetation: cultivated sector; old sector, recent sector and active channel (1, 2, 3 and 4 in Fig. 10a). In this case a total amount of 1441 PSs were detected on the alluvial fan surface, with displacements ranging from 4.1 to $-4.6 \mathrm{~mm} /$ year. Most of the detected PSs are found within recent and active channel (3 and 4 in Fig. 10a), where sparse vegetation, rock blocks and gravel is found. The detection of PSs in these sectors shows that that significant alluvial fan activity is over. Otherwise, sediment yield would imply surface changes and therefore no PSs could have been detected due to the loss of coherence. One can observe that displacement PSs are concentrated on the active channel and the old Southern sector (4 and 3 in Fig. 10a). To our knowledge, significant groundwater exploitation does not exist in this area, therefore consolidation due to groundwater withdrawal may not be expected. Nevertheless detected displacements may be due to compaction processes related to water table variations in time. Further research would be necessary to confirm the nature of the detected movement.

\subsection{Badlands areas analysis}

The term badlands describes a specific landscape characterised by poorly consolidated bedrock or unconsolidated sediment areas and the absence of vegetation. Badlands development is controlled by regolith variations, erosion and transport processes, with the latter related to the occurrence of rainstorms and floods. The regolith development is intense 


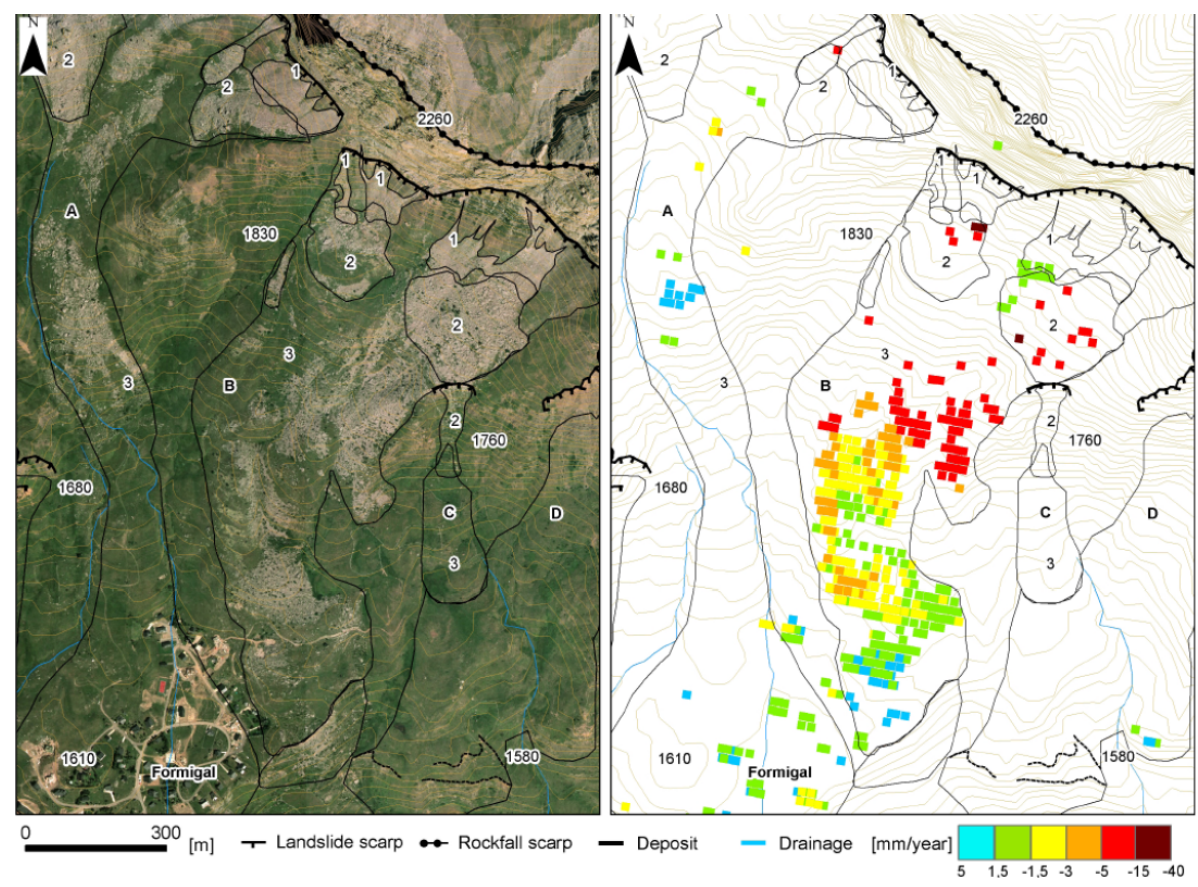

Fig. 9. Map of Formigal landslide showing the displacement velocity estimated with: the SPN technique in the analysed descending orbit datasets between 1995 and 2007.

during the cold and humid season when freeze-thaw cycles of the bedrock occur, whereas erosion and sediment transport are active from spring to mid-autumn (Nadal-Romero et al., 2007). In the Gállego River basin, Eocene marls found in the Inner Depression are the most important erodible rock substratum. A significant amount of PSs, 34\% of the total, were found in areas characterised by intense processes of soil erosion that are responsible for the formation of badlands. Within Eocene marls, a total of 65 badlands have been identified from the SPN analysis, of which $67.7 \%$ of the detected PSs correspond to displacement PSs with displacement velocity values between +1.3 to $-11.6 \mathrm{~mm} /$ year.

An example of a badland area is shown in Fig. 10b. This badland (1 in Fig. 10b) is developed between 970 and $770 \mathrm{~m}$ a.s.l and affects middle Eocene marls that occupy the glacis surface developed regularly from the base of the Sabiñánigo sandstones reliefs towards the Gállego River channel, bordered by the agricultural fields to the North and with the road to the South and East. The erosive action of the river has favoured the occurrence of small rotational landslides at the glacis river talus (4 in Fig. 10b). A total amount of 140 PSs were detected within this badland, with displacements rating from 1.3 to $-11.6 \mathrm{~mm} /$ year. All the detected PSs correspond to unvegetated areas where large rock blocks are absent. Since the SPN analysis could only measure slow displacements $(<40 \mathrm{~mm} /$ year $)$, detected PSs must correspond to areas within the badlands where runoff of the sediment has not occurred in the analysed period. Had erosion and sediment transport occurred, the PSs would not have been detected due to the loss of coherence. Therefore, detected displacements could be associated to compaction of the regolith areas that have not suffered erosion and transportation. This compaction of the regolith could be linked to the weathering freeze-thaw processes described by previous works (Nadal-Romero et al., 2007 and 2008), but further investigation would be required. Towards the North East, there is an area where 74PSs have been detected on the Eocene marls, at the edge of the Sabiñanigo sandstone relief ( 2 in Fig. 10b). Neither landslide nor badland morphologies have been identified in this area, but deformation could be related to the presence of gullying. In this area, badlands have not developed, probably due to the thinness of the erodible marls. Another explanation for these deformations could be an error introduced by the external DEM used to remove the topographic component of the interferometric phase in the SPN processing. Nevertheless, one of the outputs of the SPN processing is a height error value for every PS which has permitted those PSs displacements associated to DEM error to be discarded. More information on this topic can be found in Herrera et al. (2009).

\section{Discussion and conclusions}

This paper presents the first application of the Stable Point Network (SPN) technique to mapping and monitoring geomorphological processes in mountainous areas. A key characteristic of this algorithm is its flexibility, which enables 

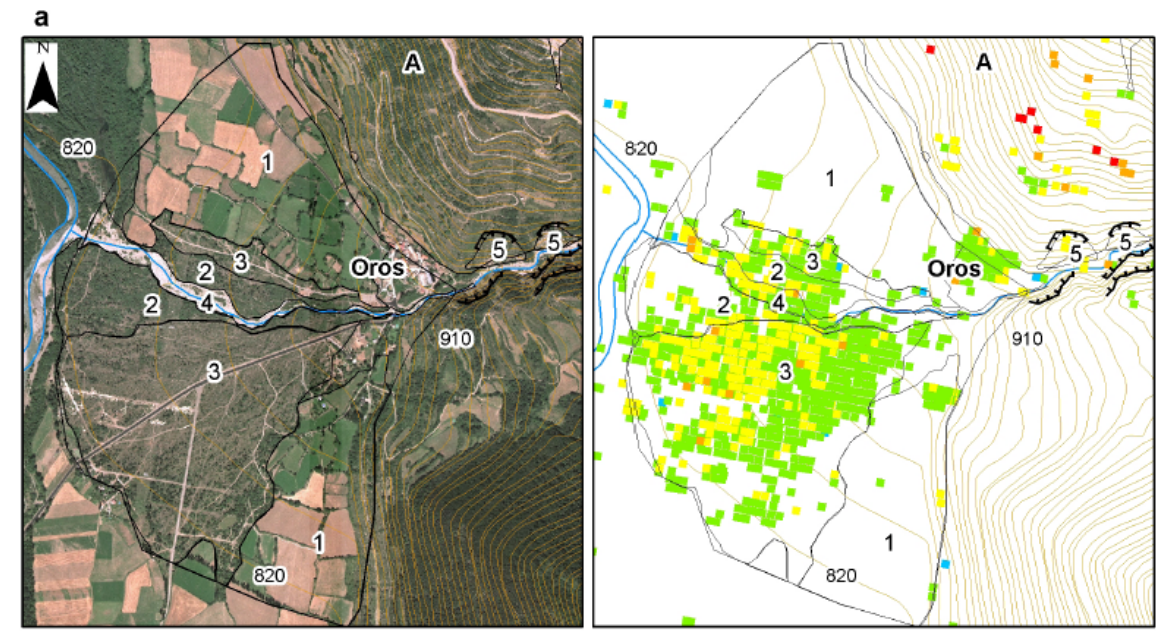

b

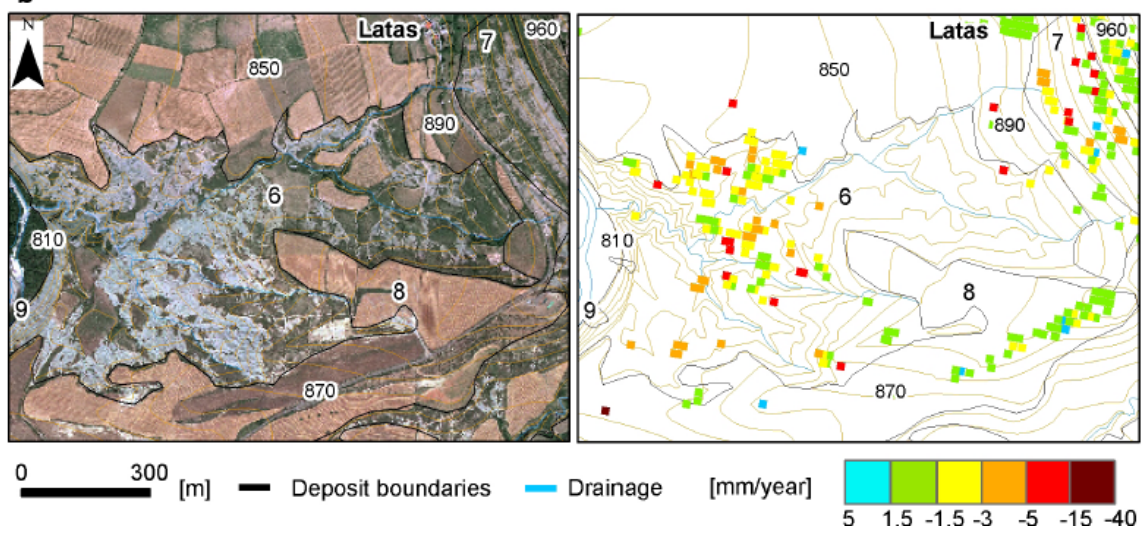

Fig. 10. a Map of the Oros alluvial fan showing the displacement velocity estimated with the SPN technique between 1995 and 2007. Figure 10b Map of Latas badlands showing the displacement velocity estimated with: the SPN technique between 1995 and 2007.

working at full resolution (4 by $20 \mathrm{~m}$ ) selecting the PS by analysing the amplitude of the set of SAR images, or at reduced resolution (for example 40 by $40 \mathrm{~m}$ ) selecting the Persistent Scatterers (PSs) by interferometric coherence. In this case, the application of the coherence-based approach has been particularly useful in the Gállego River basin because it is a non-urban and vegetated zone where ground surface natural scatterers (buildings, structures, metallic objects) are very rare and scarce, The analysis of three different SAR images datasets covering the periods 1995-2000 and 2001-2007 has permitted the detection of over 40000 PSs over the study area.

As a result $5.7 \%$ of the PSs provided information on $23 \%$ of the landslides inventoried by Mulas and Fresno (1995), with a density of $20 \mathrm{PSs} / \mathrm{landslide,} \mathrm{detecting} 31$ new landslides within this study area. Most of the displacements detected in landslides correspond to rock deposits that are transported downhill by other landslide mechanisms, such as the slow soil flows described by García-Ruiz et al. (2004) characteristic from the Upper River Gállego basin. Portalet and Formigal landslides illustrate this type of landslide mecha- nisms. The assessment of the landslide susceptibility map (Mulas and Fresno, 1995) with the SPN data has shown that there is a good correlation between landslide susceptibility and the amount of PSs, and the rate of measured displacements.

The Portalet landslide has provided an opportunity to compare ERS and ENVISAT radar satellite performance against ground based radar (GB-InSAR), available from FPW6 Galahad project. The SPN analysis could not detect PSs on the landslide triggered in 2004. In this zone GB-InSAR measured displacements of $15 \mathrm{~cm}$ in 47 days $(1095 \mathrm{~mm} /$ year $)$, which is out of the detection range of the satellite based techniques. Nevertheless, displacement PSs were detected in other parts of the Portalet landslide that could not be monitored by the GB-InSAR, providing the temporal evolution of the displacement since 1995. This comparison clearly shows that radar satellite based analysis and GB-InSAR are complementary techniques, which can be integrated in order to monitor deformation processes, like landslides, that over the same monitoring area may show very different ranges of movement. ERS and ENVISAT based applications may 
utilise historical SAR imagery available since 1991, covering wide areas $(100$ by $100 \mathrm{~km})$ with a spatial resolution of 40 by $40 \mathrm{~m}$ and a temporal resolution of every 35 days. On the other hand, GB-InSAR is operative once it is installed, covering areas of a few $\mathrm{km}^{2}$, providing a measurement of the deformation every hour of each 2 by $2 \mathrm{~m}$ detected pixel.

The SPN analysis has also permitted the detection and monitoring of other geomorphological processes that are characteristic of the Gállego River basin. In fact, alluvial fans account for $20.7 \%$ of the PSs (788 PSs/deposit), and the erosive areas represent $8.4 \%$ of the PSs (57 PSs/deposit). Such a high concentration of PSs is very surprising because these morphologies do not present rock outcrops, large rock deposits or urban structures that favour the detection of natural targets. The comparison with the pre-existing lithological maps reveals that these processes are developed on alluvial and end of the valley deposits, terraces, glacis and marls, which account for $73.8 \%$ of the detected PSs.

Most of the detected PSs in alluvial fans are stable since only $13.4 \%$ of them are classed as displacement PS. In the case of the Oros alluvial fan, most of the detected PSs are located on the recent sectors and active channel of the alluvial fan that are occupied by sparse vegetation, blocks and coarse gravels. The detection of PS in these sectors shows that significant alluvial fan activity is over -otherwise sediment yield would imply surface modifications and therefore no PSs could have been detected. To the authors knowledge, significant groundwater exploitation does not exist in this area, therefore consolidation due to groundwater withdrawal may not be expected. Nevertheless detected displacements may be due to compaction processes related to water table variations in time. Further research would be necessary to confirm the nature of the detected movement.

A significant amount of PSs were found in areas characterised by erosive processes that form badlands. These areas mostly developed on the Eocene marls found in the Inner Depression. The PSI techniques can only measure slow displacements; therefore detected PSs must correspond to areas within the badlands where runoff of the sediment has not occurred in the analysed period. Had erosion and sediment transport occurred, the PSs would not have been detected due to the loss of coherence. Therefore detected SPN displacements could be associated with compaction of the regolith areas associated to the weathering processes described by previous works (Nadal-Romero et al., 2007). The application of SPN analysis to the dynamics of badlands areas is an unaddressed topic that requires further research.

Acknowledgements. This work has been partially funded by the project SPAINSLIDES element of the of the Terrafirma Global Monitoring for Environment and Security program from ESA, by the project GALAHAD, "Advanced Remote Monitoring Techniques for Glaciers, Avalanches and Landslides Hazard Mitigation" of the EU 6FP (Global Change and Ecosystems, Contract N. 018409), and by the Spanish Geological and Mining
Institute (IGME) within project 2004051. The digital elevation model and aerial photographs used in this work have been provided by the cartographical service of the government of Aragón. The authors would like to acknowledge Marie-Josée Banwell for english language revision.

Edited by: A. Günther

Reviewed by: P. Farina and another anonymous referee

\section{References}

Aleotti, P. and Chowdhury, R.: Landslide hazard assessment: summary review and new perspectives, Bull. Eng. Geol. Environ., 58, 21-44, 1999.

Arnaud, A., Adam, N., Hanssen, R., Inglada, J., Duro, J., Closa, J., and Eineder, M.: ASAR ERS interferometric phase continuity, IGARSS 2003, 21-25 July 2003, Toulouse, France, CDROM, 2003.

Berardino, P., Costantini, M., Franceschetti, G., Iodice, A., Pietranera, L., and Rizzo, V.: Use of differential SAR interferometry inmonitoring and modelling large slope instability at Maratea (Basilicata, Italy), Eng. Geol., 68(1-2), 31-51, 2003.

Bull, W. B.: Threshold of critical power in streams, Geol. Soc. Am. Bull., 90, 453-464, 1979.

Carnec, C., Massonnet, D., and King, C.: Two examples of the application of SAR interferometry to sites of small extent, Geophys. Res. Lett., 23, 3579-3582, 1996.

Catani, F., Farina, P., Moretti, S., Nico, G., and Strozzi, T.: On the application of SAR interferometry to geomorphological studies: estimation of landform attributes and mass movements, Geomorphology, 66, 119-131, 2005.

Colesanti, C., Ferretti, A., Prati, C., and Rocca, F.: Monitoring landslides and tectonic motions with the Permanent Scatterers Technique, Eng. Geol., 68, 3-14, 2003.

Corsini, A., Farina, P., Antonello, G., Barbieri, M., Casagli, N., Coren, F., Guerri, L., Ronchetti, F., Sterzai, P., and Tarchi, D.: Spaceborne and ground-based SAR interferometry as tools for landslide hazard management in civil protection, Int. J. Remote. Sens., 27(12), 2351-2369, 2006.

Crosetto, M., Crippa, B., Biescas, E., Monserrat, O., Agudo, M., and Fernández, P.: Land deformation monitoring using SAR interferometry: state-of-the-art, Photogrammetrie Fernerkundung Geoinformation, 6, 497-510, 2005.

Crosetto, M., Biescas, E., Duro, J., Closa, J., and Arnaud, A.: Generation of Advanced ERS and Envisat Interferometric SAR Products Using the Stable Point Network Technique, Photogramm. Eng., 74(4), 443-451, 2008.

Creus, J. and Gil, M.: Clima, in: Estudio del Medio Físico y de sus Riesgos Naturales en un Sector del Pirineo Central, edited by: Rios Aragüés, S., Instituto Geológico y Minero de España, Madrid, 39-41, 2001.

Duro, J., Closa, J., Biescas, E., Crosetto, M., and Arnaud, A.: High Resolution Differential Interferometry using time series of ERS and ENVISAT SAR data, Proc. 6th. Geomatic Week Conference, 8-11 February, Barcelona, Spain, (on CD-ROM), 2005.

Farina, P., Colombo, D., Fumagalli, A., Marks, F., and Moretti, S.: Permanent Scatterers for landslide investigations: outcomes from the ESA-SLAM project, Eng. Geol., 88, 200-217, 2006. 
Ferretti, A., Prati, C., and Rocca, F.: Permanent scatterers in SAR interferometry IEEE Transactions on Geoscience and Remote Sensing 39(1), 8-20, 2001.

Ferrer, M.: Los movimientos de ladera en España, en: Reducción de riesgos geológicos en España. Instituto Geológico y Minero de España, ISBN 84-7840-226-8, 1995.

García Ruiz, J. M., Martí Bono, C., and Gómez Villar, A.: Mapa Geomorfológico: Sallent (Huesca). Estudio del Medio Físico y de sus Riesgos Naturales en un Sector del Pirineo Central. Instituto Geológico y Minero de España, Report, 35 pp., unpublished, 1995a.

García-Ruiz, J. M. and Lasanta, T.: Land use changes in the Spanish Pyrenees, Mt. Res. Dev., 10, 267-279, unpublished, 1990.

García Ruiz, J. M., Peña Monné, J. L., Martí Bono, C., and Gómez Villar, A.: Mapa Geomorfológico: Sabiñánigo (Huesca). Estudio del Medio Físico y de sus Riesgos Naturales en un Sector del Pirineo Central. Instituto Geológico y Minero de España, Report 20, 20 pp., 1995 b.

Gómez-Villar, A. and García-Ruiz, J. M.: Surface sediment characteristics and present dynamics in alluvial fans of the central Spanish Pyrenees. Geomorphology, 34, 127-144, 2000.

García Ruiz, J. M., Chueca, J., and Julián, A.: Los movimientos en masa del Alto Gállego, in: Geografía Física de Aragón, eidted by: Peña, J. L., Longares, L. A., and Sánchez, M., Aspectos Generales y Temáticos, 142-152, 2004.

Herrera, G., Tomás, R., Lopez-Sanchez, J. M., Delgado, Vicente, F., Mulas, J., Cooksley, G., Sanchez, M., Duro, J., Arnaud, A., Blanco, P., Duque, S., Mallorquí, J. J., and De la Vega-Panizo, R.: Comparison of Advanced Differential Interferometry Techniques: Murcia metropolitan area case study, ISPRS J. Photogramm., 64(5), 501-512, 2009.

Herrera, G., Fernández-Merodo, J. A., Mulas, J., Pastor, M., Luzi, G., and Monserrat, O.: Use of ground based sar data in landslide forecasting models: the portalet case study, Eng. Geol., 105, 220-230, 2008.

Hilley, G. E., Burgmann, R., Ferretti, A., Novali, F., and Rocca, F.: Dynamics of slow-moving landslides from Permanent Scatterer analysis, Science, 304(5679), 1952-1955, 2004.

Hooper, A., Zebker, H., Segall, P., and Kampes, B.: A new method for measuring deformation on volcanoes and other natural terrains using InSAR Persistent Scatterers, Geophys. Res. Lett., 31, L23611, doi:10.1029/2004GL021737, 2005.

Lorente, A., Beguería, S., Bathurst, J. C., and García-Ruiz, J. M.: Debris flow characteristics and relationships in the Central Spanish Pyrenees, Nat. Hazards Earth Syst. Sci., 3, 683-691, 2003, http://www.nat-hazards-earth-syst-sci.net/3/683/2003/.

Meisina, C., Zucca, F., Fossati, D., Ceriani, M., and Allievi, J.: Ground deformation monitoring by using the Permanent Scatterers Technique: The example of the Oltrepo Pavese (Lombardia, Italy), Eng. Geol., 88, 240-259, 2006.

Mora, O., Mallorquí, J. J., and Broquetas, A.: Linear and nonlinear terrain deformation maps from a reduced set of interferometric SAR images, IEEE T. Geosci. Remote., 41(10), 2243-2253, 2003.
MMA: Víctimas mortales debidas a desastres naturales, Banco Público de Indicadores Ambientales del Ministerio de Medio Ambiente y Medio Rural y Marino, Ministerio de Medio Ambiente, Gobierno de España, www.mma.es, 2008.

Mulas de la Peña, J. and Fresno López, F.: Estudio Geotécnico y de Riesgos Naturales. Estudio del Medio Físico y de sus Riesgos Naturales en un Sector del Pirineo Central. Instituto Geológico y Minero de España, Report, 216 pp., unpublished, 1995.

Nadal-Romero, E., Regüés, D., Martí-Bono, C., and SerranoMuela, P.: Badlands dynamics in the Central Pyrenees: temporal and spatial patterns of weathering processes, Earth Surf. Proc. Land., 32(6), 888-904, 2007.

Nadal-Romero, E., Latrón, J., Regüés, D., and Martí-Bono, C.: Temporal distribution of suspended sediment transport in a humid Mediterranean badland area: The Araguás catchment, Central Pyrenees, Geomorphology, 97, 601-616, 2008.

Pancioli, V., Raetzo, H., Campolmi, T., and Casagli, N.: Terrafirma Landslide Services for Europe based on Space-borne InSAR Data. Proceedings of The First World Landslide Forum: United Nations University, Tokyo, Japan, 81-84, 2008.

Pepe A., Sansosti, E., Berardino, P., and Lanari, R.: On the Generation of ERS/ENVISAT DInSAR Time-Series via the SBAS technique, IEEE T. Geosci. Remote., 2, 265-269, 2005.

Raetzo, H., Wegmüller, U., Strozzi, T., Marks, F., and Farina, P.: Monitoring of Lumnez Landslide with ERS and ENVISAT SAR data, Proceedings of Envisat Symposium, Montreux, Switzerland, ESA SP-636, 2007.

Raucoules, D., Bourgine, B., Michele, M., Le Gozannet, G., Closset, L., Bremmer, C., Veldkamp, H., Tragheim, D., Bateson, L., Crosetto, M., Agudo, M., and Engdahl, M.: Validation and intercomparison of Persistent Scatterers Interferometry: PSIC4 project results, J. Appl. Geophys., 68(2), 335-347, doi:10.10.1016/j.appgeo.2009.02.003, 2009.

Rott, H., Scheuchel, B., and Siegel, A.: Monitoring very slow slope movements by means of SAR interferometry: A case study from mass waste above a reservior in the Otztal Alps, Austria, Geophys. Res. Lett., 26(11), 1629-1632, 1999.

Soeters, R. and Van Westen, C. J.: Slope instability recognition, analysis and zonation, Landslides Investigation and Mitigation. Transportation Research Board, edited by: Turner, A. K. and Schuster, R. L., National Research Council, Special Report 247, National Academy Press, Washington DC, USA, 129-177, 1996.

Strozzi, T., Farina, P., Corsini, A., Ambrosi, C., Thüring, M., Zilger, J., Wiesmann, A., Wegmüller, U., and Werner, C.: Survey and monitoring of landslide displacements by means of L-band satellite SAR interferometry, Landslides, 2(3), 193-201, 2005.

Torrijo Echarri, F.: Informe sobre las inestabilidades detectadas en una ladera en las inmediaciones del Puerto de Portalet (Sallent de Gállego, Huesca), donde se está ejecutando la construcción de un futuro aparcamiento, Technical Report, Ilustre Colegio Oficial de Geólogos de Aragón, Zaragoza, Spain, unpublished, 2005.

Werner, C., Wegmüller, U., Strozzi, T., and Wiesmann, A.: Interferometric point target analysis for deformation mapping, Proceedings of IGARSS 2003, 21-25 July 2003, Toulouse, France, CDROM, 2003. 